\title{
Sobre a Humilhação no Cotidiano do Emprego Doméstico*
}

\author{
Jefferson Belarmino de Freitas
}

Instituto de Estudos Sociais e Políticos (IESP), da Universidade do Estado do Rio de Janeiro (UERJ), Rio de Janeiro, Brasil.

\section{"ELAS ESTÃO COM A BOLA TODA": 0 EMPREGO DOMÉSTICO EM PÉ DE GUERRA NO CONTEXTO PAULISTANO}

11 las estão com a bola toda". Isto é o que assegura o título da prin-

¿ cipal reportagem da revista Veja São Paulo, publicada em 11 de maio de 2011. "Elas" não são, todavia, profissionais liberais bem-sucedidas, políticas em cargo de alto escalão ou acadêmicas altamente conceituadas nos quadros da produção científica nacional. Sendo assim, não se dirigem, em seu cotidiano, para espaços sociais como escritórios, reuniões políticas ou congressos científicos. Na verdade, seu local de trabalho se dá, em muitos dos casos, nas residências de pessoas que costumam se dedicar a ocupações semelhantes àquelas. "Elas" são as empregadas domésticas.

O título da reportagem pode parecer, em princípio, despretensioso, ou até cômico. Longe disso. Ele sumariza uma interpretação cada vez mais difundida na cidade de São Paulo no que concerne às atuais dinâmicas do emprego doméstico que ali se configuram ${ }^{1}$. Conseguiu-se, para os fins da reportagem, captar a ideia sustentáculo dessa interpretação a partir de um comentário feito por uma empregada doméstica entrevistada: "Não tenho medo de ser demitida. Se quiser, arranjo ou-

\footnotetext{
* Agradeço à pesquisadora Flávia Rios pelas sugestões feitas a partir da leitura de uma versão preliminar deste texto. Agradeço igualmente aos pareceristas anônimos de Dados, cujos apontamentos ajudaram a enriquecer a versão final deste artigo.
}

DADOS - Revista de Ciências Sociais, Rio de Janeiro, vol. 57, nº1, 2014, pp. 199 a 236. 
tro emprego amanhã. O jogo virou para o nosso lado. Agora as patroas estão nos tratando melhor" (Veja São Paulo, 2011:37, ênfases originais).

Comentários como este são dirigidos a um "nós implícito", que já se encontra subtendido desde a apresentação da reportagem. Afinal, ao "Elas estão com a bola toda" se contrapõe outro sujeito, mas este já conjugado na primeira pessoa do plural: "nós, as patroas". Desnudado esse sujeito, outro título para a matéria poderia ser facilmente esboçado: "Nós, as patroas, estamos em perigo"; sentir-se-iam assim pois "Foi-se o tempo em que as domésticas tinham de disputar vaga de trabalho. Hoje, são as patroas que encaram fila de espera. Com salários cada vez mais altos, as empregadas passaram a apitar as regras do jogo" (ibidem:32). A abordagem das atuais dinâmicas da ocupação ${ }^{2}$, tal como formuladas nas páginas da revista paulistana, é elaborada com o intento de passar ao leitor um verdadeiro clima de guerra entre patroas e domésticas - o qual, como veremos, não deixa de ser real em certo sentido. Em poucos momentos da reportagem as vozes das empregadas domésticas deixam de soar altivas (por vezes mesmo, petulantes); ao contrário, é raro que as patroas não apareçam dramaticamente vitimadas pelo receio de perderem as suas trabalhadoras, e/ ou amedrontadas pela iminência de terem que pagar altos salários pelos seus serviços. Seja qual for o caso, há sempre um clima de desconfiança na relação entre ambas, como atesta uma doméstica entrevistada: “Tive uma patroa que gostava de me testar. Ela deixava várias notas de 50 reais espalhadas pela casa. Era oncinha para todo lado. Um dia perguntei: 'Você acha que só porque eu sou empregada vou te roubar?'". (Veja São Paulo, 2011:37, ênfases originais)

Apesar de todo o esforço, a reportagem não consegue passar, de maneira uníssona, uma imagem do emprego doméstico envolto pelos ventos da bonança no contexto paulistano. Bem alheias a essa percepção, há, registrados na reportagem, depoimentos de trabalhadoras que, diante das dificuldades enfrentadas, acreditam, por exemplo, que os seus serviços prestados, nesse ou naquele lar, têm um prazo determinado devido aos embates diários com o modo de ser de algumas patroas: "Fico no máximo dois anos em cada casa. Mais do que isso não dá certo. As patroas se acostumam com a nossa cara e ficam folgadas (ibidem)".

Ainda no leque de reclamações das domésticas existe espaço para reivindicações mais diretamente ligadas à falta de direitos trabalhistas; novamente, a visão otimista do emprego doméstico expressa na revis- 
ta, mais evidente em sua linha argumentativa do que nos depoimentos registrados, acaba por ser esmaecida: "Trabalho três vezes por semana na casa de uma família que não me registra. Isso não está certo. São ótimos patrões, mas estou descontente (ibidem)."

E como as entrevistadas poderiam deixar de relatar o desconforto acerca do estigma que a ocupação carrega, o mesmo que faz das domésticas pessoas maculadas socialmente e que ataca, assim, pontos nodais de sua autoestima? "Às vezes as nossas próprias amigas têm preconceito contra a gente. Mas ganhamos mais que muita secretária, recepcionista e vendedora de loja" (ibidem). Localizadas do outro lado da guerra, a maioria das empregadoras se mostra amargamente descontente com a qualidade do serviço que lhes é oferecido. Pesa, para a caracterização de sua opinião negativa, um abrangente rol de acusações, dentre as quais se destacam: indolência, falta de profissionalismo, de honestidade, atrevimento e mesmo arrogância. Indignadas, veem todos esses traços sendo cristalizados cotidianamente nas atitudes das trabalhadoras. Uma frase em especial sintetiza bem esse sentimento de insatisfação das contratantes: "Elas são inimigas pagas" (ibidem).

Como se vê, a tônica da Veja São Paulo quanto ao emprego doméstico, seguida à risca de modo quase unânime por outros veículos de comunicação ${ }^{3}$, é simples: enfatiza, em primeiro lugar, a soberba das domésticas, caracterizada pelo seu suposto maior poder de barganha na ocasião das negociações de emprego; em segundo lugar, salienta o presumido bom momento pelo qual passa o emprego doméstico em São Paulo, cujo mote são os salários mais elevados da categoria, estes em comparação com outros tempos, outras unidades federativas do país, e até com algumas outras profissões ${ }^{4}$.

Julgando-se de mãos atadas, os(as) empregadores(as) complementam as falas anteriores reclamando que, na ausência de domésticas que considerariam ideais (e portanto, nesta perspectiva, impossíveis de serem encontradas no mundo real), e/ou devido à alegada falta de dinheiro para pagá-las satisfatoriamente, acabaram se adequando ao serviço que lhes é prestado, embora demonstrando profundo descontentamento ${ }^{5}$. Movidas por essa sensação, elas acreditam ser vítimas contumazes das mulheres que contratam: “Não posso pagar muito, então fecho os olhos para um monte de coisas. Quando vejo um encardido, começo a contar até dez. Trabalho fora e não posso ficar sem empregada. Meu lema é: ruim com ela, pior sem ela (ibidem)." 
É finalmente chegada a hora de deixar para trás o argumento central da reportagem. Ele não expressa uma realidade plausível acerca do emprego doméstico em São Paulo. Entretanto, antes de prosseguirmos, devemos dar atenção à assertiva vindoura. Por meio dela, uma patroa entrevistada destaca a existência de uma suposta fragilidade emocional que acompanha as domésticas: estas sentir-se-iam inferiorizadas devido ao status de sua ocupação, melindrando-se facilmente frente às obrigações que a mesma requer. Segundo as patroas, tal sentimento de inferioridade seria uma trava que as impede de desempenhar sem amarras o papel de plena mandante, isto é, o papel da detentora de poder da relação: "As empregadas não gostam de sua condição. Sentem-se inferiores. Mesmo quando você chama a atenção sutilmente, elas se sentem ofendidas (ibidem)."

Não há, em toda a reportagem, relato mais central que este. Nele está implícito o fato de que as empregadas domésticas sentem-se "inferiores" e se "ofendem" facilmente, porque o seu cotidiano de trabalho é profundamente marcado por diversas situações de humilhação. Ao afirmar isso, estamos aptos a apresentar o objetivo principal deste artigo: indicar, a partir do contexto paulistano, as faces mais centrais das situações de humilhação que operam no cotidiano do emprego doméstico. Atribuir substância teórica e empírica a esse objetivo significa trazer, para o vasto campo das ciências sociais, ao menos duas contribuições principais: a primeira delas, mais geral, consiste em colocar as situações de humilhação no reino dos fenômenos coletivos que precisam ser objeto de estudo de tais ciências, tendo em vista que movimentam o curso das interações sociais, reproduzindo e perpetuando, assim, relações de poder; a segunda contribuição, mais específica, diz respeito ao fato de que as situações de humilhação são, nesses moldes, um acontecimento indissociável ao cotidiano do emprego doméstico, sendo inclusive fortalecidas em tal cotidiano.

Cabe indicar que o nosso percurso analítico é motivado pelas seguintes questões: quais são as principais características das situações de humilhação que agem sobre o encontro entre empregadores(as) e empregadas domésticas? Em que medida essas situações de humilhação regem tal encontro? Quais são as suas implicações, sobretudo para a vida das trabalhadoras? Conforme o leitor verá, argumentamos, em diálogo com as questões apresentadas, que as humilhações das quais o emprego doméstico se vale estão ligadas, em maior ou menor grau, à distância social que orienta o contato entre os(as) empregadores(as) e 
suas contratadas, razão que faz esse contato ser marcado, em grande medida, por conflitos.

Já há pistas sobre o peso das humilhações moldadas pelo emprego doméstico no desabafo introdutório, que se segue. Retirado de uma das entrevistas que fiz, ele indica que a incapacidade de superar o sentimento de humilhação incorporado, e o convívio interno com ele por alguns meses, configurou-se como uma situação explosiva para Simone. Fortemente angustiada por essa experiência, a trabalhadora pediu, ao fim, demissão de uma casa onde trabalhou: "Aí nesse dia eu fiquei chateada, revoltada, e passou uns três quatro mês eu pedi as conta. Eu fiquei muito humilhada aquele dia" (Simone, 32 anos, 2010).

Relatos dessa ordem se multiplicarão nas próximas páginas. Eles irão, por si só, pôr em xeque a ideia de que as domésticas viveriam um momento de supremacia nas residências onde trabalham. Como veremos, essa suposta supremacia mostra-se incompatível com as situações de humilhação que se apoderam de seu cotidiano ocupacional. Mas, antes de verificarmos o peso das humilhações no cotidiano do emprego doméstico, vejamos a sua pertinência conceitual e analítica em sentido mais amplo.

\section{HUMILHAÇÃO: IMPORTÂNCIA HISTÓRICA E CONCEITUAL}

A importância social e conceitual das situações de humilhação não nasceu a partir de observações direcionadas ao cotidiano do emprego doméstico. Por isso, neste momento, indicaremos a sua aparição em contextos variados. Certamente, tais situações de humilhação sempre estiveram operando no encontro entre empregadores(as) e empregadas domésticas, mas permaneceram, ao longo dos anos, adormecidas nas formulações científicas elaboradas pelos pesquisadores que investigaram as entrelinhas da ocupação.

Na verdade, a humilhação nunca foi protagonista sequer nas cartilhas mais famosas das ciências sociais. Ainda assim, é possível percebê-la direcionando alguns fenômenos importantes ao longo da história. Decerto, recorrer à humilhação para demonstrar soberania não é uma atitude que faz parte tão somente do modo de vida de grupos ocidentais. Marcel Mauss (1975) fortalece essa observação, dado que registrou dinâmicas repletas de humilhação em seu paradigmático Ensaio sobre a Dádiva. 
Atento como poucos, Mauss (1975) percebeu, já na virada do século XIX, que as situações de humilhação encontravam força em ações coletivas. Isto ocorria, principalmente, entre os grupos indígenas da América do Norte e de ilhas localizadas na região do Oceano Pacífico, os quais agiam, em grande medida, impelidos pelo objetivo de esbanjar altivez e demarcar peremptoriamente os seus espaços de poder. Encontravam vazão para isso em práticas como a do potlatch, cerimônia que consistia, justamente, na cessão de bens valorizados por esses grupos; quanto mais esses bens fossem apreciados no contexto das trocas, mais denotavam a superioridade do doador.

A humilhação inerente a esse cerimonial de imponência reside, sobretudo, no fato de a pessoa receptora sentir-se socialmente constrangida a devolver a dádiva recebida com outra que possuísse valor social equivalente, ou, preferencialmente, maior; somente neste último caso conseguiria reverter o processo de humilhação que lhe fora aplicado na ocasião da vinda do presente. É por essa razão que Mauss (ibidem:176) enfatiza que, se porventura a retribuição demorasse a acontecer, o receptor se esforçava, na medida do possível, para devolvê-la "com juros, mas para humilhar o primeiro doador ou trocador, e não somente para recompensá-lo pela perda que lhe causa um consumo adiado". Com isso, tem-se aplicado um dos principais fins do potlatch: impor soberania, inferiorizando o receptor da dádiva por meio de um constante recurso à prodigalidade.

Todavia, apesar de precursora, não foi a pesquisa de Mauss que transformou de vez as situações de humilhação em tema digno de ser analisado pelas ciências sociais. Para que isso acontecesse, elas iriam precisar garantir lugar central no curso da história moderna ocidental, o que apenas se deu a partir da ascensão do regime nazista. Conforme aponta De Decca (2005:105)

Na literatura das ciências humanas o estudo da humilhação é relativamente recente e passou a ser objeto de reflexão a partir da ascensão do nazismo. Apesar de se constituir em questão muito sensível no plano da moral e da ética, não tinha merecido a devida atenção das ciências sociais, até que a experiência nazista tivesse mostrado a sua face de terror.

Contudo, nenhuma situação de humilhação é mais atual do que a que envolve jovens, principalmente no interior de instituições de ensino mundo afora; por serem engendradas por ações que visam atacar a constituição física e/ou psicológica de estudantes estigmatizáveis, 
relegando-os, assim, a um local de inferioridade social acachapante, tais humilhações têm sido, no geral, classificadas sob nova rubrica: bullying. Notando isso, De Decca (2005:115) escreve:

Devemos fazer uma avaliação dos inúmeros significados da humilhação em sociedades não hierárquicas e podemos indicar, dentre outros, um novo conceito muito utilizado hoje nas sociedades europeia e americana. Refiro-me aqui ao conceito de bullying (o termo bullying compreende todas as formas de atitudes agressivas, intencionais e repetidas, que ocorrem sem motivação evidente, adotada por um ou mais estudantes contra outro(s), causando dor e angústia, e executadas dentro de uma relação desigual de poder. Portanto, os atos repetidos entre iguais [estudantes] e o desequilíbrio de poder são as características essenciais que tornam possível a intimidação da vítima) e que podemos traduzir também por humilhação.

Entretanto, para alguns pesquisadores, a recorrência histórica e a força coletiva do ato de humilhar não garantem, por si só, a sua pertinência analítica. Solomon (2000) traz esse questionamento à tona, ao abordar a humilhação como um fenômeno pertencente ao reino das emoções. Ao fazê-lo, abranda o seu caráter de anônima, colocando-a, assim, em primeiro plano, no nível das interações interpessoais, face a face. É a partir desse ângulo que o pesquisador afirma que toda contenda que impulsiona os debates filosóficos sobre o tema gira em torno da seguinte questão: existiria, de fato, uma calculada intencionalidade por parte do agente que humilha? Vale a pena atentar para o imbróglio conceitual para o qual o autor chama a atenção:

uma maneira de enfatizar que as emoções têm um componente cognitivo - que elas não podem ser simplesmente sentimentos ou processos fisiológicos, ou mesmo frações "impensadas" de comportamento - é insistir que elas têm "intencionalidade". "Intencionalidade" é uma noção técnica, mas o seu significado no senso comum pode ser capturado pela ideia segundo a qual os sentimentos são sempre "sobre" algo ou outro [...]. Mas intencionalidade também vem sendo objeto de consternação filosófica por mais de um século, pois, apesar de seu apelo enquanto uma forma de entender a natureza da percepção e outros "atos" mentais (que nos levam para longe da imagem das imagens ou representação "na" mente), intencionalidade tem as suas próprias complicações peculiares. O mais problemático para os filósofos é o fato óbvio de que uma emoção pode ser "sobre" algum objeto inexistente, meramente imaginado. (Solomon, 2000:12)

Lukes (1997) é ainda mais descrente. Ao refletir sobre a recepção das humilhações também no plano interpessoal, o sociólogo enfatiza que 
existem configurações sociais nas quais elas podem ser simplesmente supervalorizadas - ou seja, podem existir apenas na cabeça das pessoas que se julgam vítimas. Critica, assim, a recepção das humilhações, mais do que a sua intencionalidade. Dentre outros casos, elas poderiam ser supervalorizadas mais acentuadamente por pessoas excessivamente passionais, as quais tenderiam, portanto, a se melindrar facilmente frente a qualquer tipo de desacordo; por grupos dogmáticos das mais diversas ordens (fundamentalistas religiosos, por exemplo); e/ou por pessoas espertalhonas que, por qualquer razão que lhe sejam vantajosas, vejam no ato de se autovitimizar uma estratégia que poderia lhe trazer benefícios. Em vista disso, Lukes questiona:

É fácil listar exemplos de vítimas de racismo ou outros tipos de perseguição cujas pressuposições para tanto sejam indubitáveis. Mas o que dizer daquelas pessoas que são especialmente vulneráveis a insultos e ofensas por causa de suas crenças dogmáticas, ou por causa de seus temperamentos passionais, ou cujas oportunidades para mobilizar tais vulnerabilidades possam lhes trazer benefícios? (Lukes, 1997:50)

Lukes é reducionista neste ponto. Por mais que sejam passíveis de diferenciações interpretativas, as situações de humilhação sempre encontram espaços para sobreviver, pois são amplamente validadas por forças supraindividuais. São, portanto, um fenômeno social e, enquanto tal, não podem ser reduzidas ao nível de melindres idiossincráticos, ou serem vistas como cegas reações dogmáticas. Seu combustível maior são as desigualdades correntes socialmente; daí se colocarem na figura de pessoas propensas ao peso das estigmatizações sociais - caso típico das empregadas domésticas.

Quando ganha forma, a humilhação opera de modo coeso, se assentando em situações nas quais alguém quer impor soberania. Não é, desse modo, meramente circunstancial. Se alimenta de crenças partilhadas e sinais de poder construídos em espaços sociais diversos (sejam eles públicos ou privados) que fazem o humilhado quase sempre se dar conta de que muitas das cordialidades presentes nas interações cotidianas não são estendidas a ele, e que algumas das benesses criadas no mundo moderno (leis, bens, espaços de lazer etc.) não foram concebidas para contemplá-lo. A reflexão de Gonçalves Filho reforça essas observações ao estabelecer que

A violência que machuca o humilhado nunca é meramente a dor de um indivíduo, porque a dor é nele a dor velha, já dividida entre ele e seus irmãos de destino. Os ataques, quanto mais nos chegam de fora e de mui- 
to antes, tanto mais nos vão paradoxalmente atacar de dentro e agora. Distantes e antigos, ficaram mais ou menos sem sentido, embora imbuídos de uma energia difícil de conter: machucam muito, corrosivamente [...]. O humilhado não sabe bem por que chora e nunca chora apenas por si próprio, chora a dor enigmática e chora a dor somada. (Gonçalves Filho, 2007:7)

Como se vê, há formas de humilhação que correm sozinhas, anônimas, uma vez disseminadas por forças sociais amplamente amparadas por desigualdades sociais construídas no curso da história. Seu poder é devastador e quase onipresente. Mas, no decorrer do dia a dia, elas são incorporadas por pessoas, ganhando, assim, vozes e gestos, e agindo com vistas a um fim determinado: demonstrar soberania. É com essas palavras que resgato o caráter racional do ato de humilhar, aplicando-o, nas próximas seções deste artigo, ao cotidiano do emprego doméstico paulistano. Faço isso porque a racionalidade da humilhação engendra uma intencionalidade máxima: rebaixar um oponente. Isto significa, em certo sentido, distanciar-se socialmente desse oponente numa dose extrema, colocando nele, a marca social da inferioridade:

Humilhação significa forçar o rebaixamento de uma pessoa ou grupo, um processo de sujeição que abala e destrói o orgulho, honra ou dignidade. Em seu cerne está a ideia de rebaixamento, de colocar a pessoa ou o grupo no nível do chão. Trata-se, em nosso entender, de uma conduta, ou melhor, de uma ação social, e aquele que humilha, age visando atingir algum objetivo. (De Decca, 2005:108; ênfase minha)

Assim, forças coletivas anônimas são, em algum momento, transformadas em atos racionais, intencionais. A partir disso, situações de humilhação se personalizam, atuando em ocasiões nas quais alguém julga ser necessário demarcar poder e, deste modo, manter os seus privilégios concedidos e validados socialmente. Em poucos espaços essa dinâmica se configura com tanta força quanto no cotidiano do emprego doméstico.

\section{HUMILHAÇÃO NO EMPREGO DOMÉSTICO: PRÓXIMA DA DISCRIMINAÇÃO, DENTRO DA DISTÂNCIA SOCIAL}

Até hoje pouco se atentou para o fato de que o cotidiano do emprego doméstico cria um modo de humilhação bastante particular. A chave para entender os significados desse modo de humilhação encontra-se diretamente ligada ao papel que a distância social ${ }^{6}$ preenche nas inte- 
rações cotidianas das patroas com as empregadas domésticas. Cabe dizer, todavia, que a humilhação à la emprego doméstico não se consuma por meio de qualquer nível de distância social; trata-se de um nível, por assim dizer, amplificado, que ganha vida com base em um jogo de ação e reação entre os dois grupos sociais protagonistas da ocupação.

Quem se vê envolvido em uma situação na qual operam atitudes controladas por um alto nível de distância social comumente as classifica como extremamente ríspidas. Por essa razão, a humilhação que ataca as domésticas faz com que estas muitas vezes considerem que tenham sido, literalmente, discriminadas. Essa classificação não é um exagero em sua lógica; tanto que, para elas, um dos parâmetros básicos para caracterizar um(uma) bom(boa) contratante é, em linhas gerais, a efetiva ausência de discriminação em sua maneira de agir. No reino da discriminação, as trabalhadoras incluem o fato de serem tratadas como invisíveis, ou, simplesmente, como meras empregadas ${ }^{7}$ :

Ele acha que você tá ali; é um empregado. Ele não te dá bom dia nem boa tarde. Já hoje eu tenho um bom patrão. Ele me trata como uma pessoa da família, não como uma empregada. Hoje pra mim sim é..., um bom patrão é esse..., que ele vê como é a sua vida, não é discriminando você (Lúcia, 35 anos, 2006).

Algumas patroas expressam um ponto de vista semelhante, quando incitadas a refletir sobre o porquê de tantas queixas de humilhação por parte das domésticas: "Eu interpretaria que humilhação, por exemplo, é não tratar igual, fazer diferença entre os da família e o dela, discriminar alguma coisa que é importante. Bom, a minha [doméstica] não há necessidade nenhuma [de reclamar] (Dona Cristina, 74 anos, 2010)" ${ }^{\prime \prime}$.

Os rituais de imposição de poder presentes no dia a dia do emprego doméstico aproximam humilhação e discriminação. Entretanto, é nosso papel indicar que ambas não possuem o mesmo peso conceitual. Humilhação ganha forma quando alguém tenta atacar veementemente outra pessoa, a qual, em uma situação em que predomina a necessidade de distanciamento, é posta na categoria de oponente. De modo bastante aberto, a intenção desse ataque premeditado é deixar a pessoa-alvo sem defesa, sentindo-se, dessa forma, devastada. Não consegue encontrar reação possível.

Os atos de discriminação, por sua vez, se reproduzem de maneira mais sorrateira. Adequam-se, sem maiores problemas, ao cotidiano de qualquer instituição, ganhando forma quando alguém é tratado diferen- 
cialmente, por exemplo, por fazer parte de algum grupo estigmatizado socialmente $^{9}$ (seja por sua pertença regional, racial, de classe, gênero etc.). Esse conjunto de manobras de exclusão sussurrada vem geralmente à tona quando, aos olhos do discriminador, uma pessoa marcada socialmente tenciona fazer parte de um espaço social tornado, por anos, indisponível ao grupo de origem ao qual é relacionado.

Por acontecerem, no geral, de modo velado, os atos de discriminação tornam-se difíceis de serem combatidos. Assim, caso decida enfrentá-los, a pessoa que se julga perseguida quase sempre terá que se opor a uma afronta que muitos consideram inexistente - de acordo com comentários correntes, classificada como mero fruto de sua imaginação, ou, mais frequentemente, de sua baixa autoestima ${ }^{10}$. Esse jogo de perseguição baseado no escamoteamento não é característico às situações de humilhação. Quando alguém quer humilhar outrem, o faz sem deixar frestas para dúvidas.

Contudo, mesmo não sendo idênticos em termos conceituais, nos locais em que a imposição de poder é atuante, humilhação e fenômenos como preconceito e discriminação podem possuir fins bastante similares. Elias e Scotson (2000) constataram essa proximidade de objetivos quando elaboraram o seu famoso estudo de caso em uma cidadezinha nomeada, ficticiamente, Wiston Parva.

Ao investigarem as dinâmicas sociais preponderantes na cidade, os sociólogos descobriram que humilhar os moradores recém-chegados, de modo a manter os seus privilégios e soberania, era uma das principais armas utilizadas pelo grupo dos estabelecidos locais. Faziam isso com base em estigmatizações de diversas ordens. Muitas delas, cabe pontuar, eram bem pouco sofisticadas, embora atingissem o seu fim primordial. Costumavam, por exemplo, maximizar todas as atitudes que caracterizavam como deturpação social (valendo-se, inclusive, de fofocas para macular o grupo social que viam como opositor), tornando público que tais atitudes feriam, a seu ver, o código de condutas que se esforçavam para impor. Desse modo, demonizavam os vistos como outsiders, ao mesmo passo em que santificavam a si próprios.

Postos no papel de outsiders, os recém-chegados são percebidos pelos estabelecidos como pessoas "que não conhecem seu lugar"; agridemlhes a sensibilidade, portando-se de um modo que, a seu ver, traz claramente o estigma da inferioridade social; no entanto, em muitos casos, os grupos dos recém-chegados tendem inocentemente a se conduzir, ao 
menos por algum tempo, como se fossem iguais a seus novos vizinhos. Os mais "antigos" levantam sua bandeira, lutam por sua superioridade, seu status e seu poder, seus padrões e suas crenças, e em quase toda parte utilizam, nessa situação, as mesmas armas, dentre elas os mexericos humilhantes, as crenças estigmatizantes sobre o grupo inteiro, com base em observações sobre seu pior setor, os estereótipos verbais degradantes e, tanto quanto possivel, a exclusão de qualquer oportunidade de acesso ao poder - em suma, as características que costumam ser abstraídas da configuração em que ocorrem sob rótulos como "preconceito" e "discriminação" (Elias e Scotson, 2000:174-175; ênfases minhas).

Todavia, a situação das empregadas domésticas que trabalham nas residências da Região Metropolitana de São Paulo (doravante, RMSP) é ainda mais drástica do que aquela que marcava a sorte dos outsiders de Wiston Parva; isso porque, a pesar de todas as barreiras criadas, existia, naquela cidade, uma evidente procura por equiparação de status. Se quisermos utilizar outras palavras, podemos dizer que fazia parte do horizonte dos seus outsiders uma busca por mobilidade social, por mais que esta lhes fosse dificultada. Desse modo, ainda que vissem algumas portas se fecharem, eles ainda podiam sonhar em atingir, certo dia, o título de estabelecidos, ou, pelo menos, vislumbrar estarem muito próximos destes em termos de prestígio social.

Possibilidades como esta não estão abertas para as empregadas domésticas da RMSP. A sua inserção nas casas em que prestam serviços é profundamente regida por uma desigualdade intrínseca e, em última instância, insuperável. Em seu local de trabalho, não existe a rota aliviadora da mobilidade. Ninguém as contrata abrindo a possibilidade para que se transformem, em algum momento, em chefes do lar onde trabalham. O emprego doméstico é, assim, pouco maleável. Só há um espaço de comando no contrato social que regula o seu funcionamento, e este espaço não deve ser preenchido pelas domésticas.

Apesar disso, aquelas que vivem do emprego doméstico se esforçam para conseguir melhores condições de trabalho; e, sobretudo por se ocuparem do espaço doméstico, local onde a informalidade impera, controlada pela força da intimidade, esperam um bom tratamento por parte de seus(suas) contratantes. Mas, enquanto presas ao (e do) emprego doméstico, as trabalhadoras têm plena consciência de que a elas está reservado um lugar social bastante delimitado. Diante disso, domésticas mais experientes apresentam uma atitude bastante defensiva: 
Cada coisa no seu lugar. Você pode ter amigo, ser amigo do patrão, mas dentro do padrão dali. É amigo, você trabalha, ele é o seu patrão, você pode ser amigo, mas tudo no devido lugar. Não é você confundir porque é amigo, confundir a liberdade com a amizade.

[...]

Eu sempre tive amizade e nunca tive problema, graças a Deus. Porque o tempo de trabalho seu multiplicado, você pode ter amizade, pode não ter. Se o patrão não tiver consciência, o trabalho multiplica mesmo. Pode ser amigo, pode não ser (Dona Marisa, 44 anos, 2010).

Os laços de amizade que surgem nas interações cotidianas do emprego doméstico nunca atingirão igualdade plena, sequer considerável, pois estão inundados em um contexto de disparidade de poder marcante ${ }^{11}$. Por isso, os vínculos amistosos eventualmente desenvolvidos com os(as) empregadores(as) não apagam a humilhação e a discriminação do dia a dia do emprego doméstico. No âmbito da ocupação, duas razões principais explicam a linha tênue entre o aberto ato de humilhar e o escamoteado ato de discriminar: em primeiro lugar, a intrínseca desvalorização social da ocupação; em segundo, a limitação do que é ou não permitido às domésticas, num ambiente em que a intimidade de cada lar ora lhes é docilmente oferecida, ora abruptamente retirada.

Vale dizer, porém, que "a exclusão de qualquer acesso ao poder", explicitada por Elias e Scotson (2000) em seu estudo, não faz parte do rol de preocupações de quem contrata uma doméstica. Em vez de trancar os seus valores a sete chaves - como tentavam fazer os estabelecidos em sua resistência em partilhar espaços com os outsiders, isto é, em sua persistência em se distanciar socialmente destes - as patroas, ao contrário, passam tais valores àquelas a quem contratam, visto que, na interação das patroas com as empregadas domésticas, a busca por uma equiparação de status está fora de perspectiva. O distanciamento social intrínseco ao emprego doméstico é, neste caso, recorrentemente garantido pelo seguinte axioma: tais valores, uma vez repassados, o são para corrigir hábitos sociais, entretanto, sempre a cargo do servir - e, mais precisamente, do servir bem. O desconforto expresso por uma entrevistada confirma essa observação:

Porque, você trabalha de doméstica..., o que que vai acontecer? Na sua casa, se a minha louça... se eu quiser deixar a minha louça na pia hoje, eu vou deixar. Eu não vou lavar. Eu não sou obrigada a lavar, tá? Se eu não quiser lavar roupa hoje, eu não vou lavar. E uma doméstica, não. Ela tem que fazer. Seja qual for o dia da semana, ela vai ter que fazer. Por 
quê? Porque ela tá sendo paga pra isso. Então ela não tem o que questionar. Porque, se ela questionar o que que vai dizer? Você é doméstica. Você foi contratada pra fazer. Você foi contratada pra me servir (Rosa, 41 anos, 2010).

Não raro, conflitos no interior do emprego doméstico independem da boa ou má índole das patroas, ou do eventual temperamento explosivo das domésticas. Eles estão lá no cotidiano da ocupação, em ponto de espera, sempre prestes a acirrar os ânimos de seus agentes sociais. Assim, nem mesmo contando com a servidão em seu favor - que, no geral, tende a colocar as relações sociais do emprego doméstico no modelo de hierarquia social que ele sustenta -, as patroas conseguem se livrar de embates, em muitos casos, ríspidos. Vale acentuar, nesse sentido, que o emprego doméstico, quando imerso em centros urbanos, está cada vez menos suscetível a adequar-se a um modelo de hierarquia social no qual a subserviência é aceita sem resistência. Isto ocorre, em grande medida, porque uma desconfiança mútua toma conta de seu cotidiano. Como bem aponta Vidal (2009:182), "as relações das trabalhadoras domésticas e seus patrões são relações em que nenhuma das duas partes confia inteiramente na outra". Quando essa desconfiança atinge níveis incontornáveis, rompe-se o contrato que modera o emprego doméstico.

Diante disto, as empregadoras precisam agir com alguma perspicácia e sutileza, sobretudo nos momentos em que necessitam dar ordens e retirar destas o resultado desejado. Em nossos termos, precisam ajustar (sem exacerbar) a distância social sempre posta entre elas e suas contratadas. Kofes (2001) flagrou elementos desse jogo sutil em um manual publicado no final da década de 1970. Neste manual, sua autora, Kaufmann, indica diversas manobras para extrair eficiência das domésticas, manobras estas que deveriam ser feitas sem que se perdesse de vista uma precaução essencial: não ferir o brio das trabalhadoras ${ }^{12}$. Em outras palavras, sem humilhá-las. Assim, diante da incapacitação das domésticas em se adequar ao mundo de suas contratantes, sempre classificado como superior, a estas últimas caberia uma tarefa quase sempre árdua, porém essencial: a de domesticar as primeiras. Segundo o registro original de Kofes (2001:82): “[...] em seu manual sobre a relação entre patroas e empregadas, Kaufmann refere-se a estas últimas como '[...] um festival de incompetência que as patroas, com maior ou menor habilidade, têm que domesticar, às vezes domar como bicho bravo'". 
A caracterização da doméstica como alguém que precisa ter os hábitos corrigidos para que seja, assim, adaptada ao mundo dos bons costumes é disseminada nos mais diversos espaços sociais. Oliveira (2007) presenciou fortes traços dessa dinâmica quando decidiu ser aluna em um curso para qualificação de domésticas, na cidade de Campinas, SP. Adotou esta estratégia para entendê-lo em suas minúcias, e para tentar viver um pouco a experiência do eterno "outro" que é a doméstica. Rotulou a correção de hábitos e valores, temas centrais das aulas que presenciou, como componentes de uma estratégia de modelagem que incide sobre o comportamento e costumes das trabalhadoras. Registrou o seguinte, a partir de sua incursão:

O que se verifica dessa maneira é que tanto a ênfase técnica como comportamental postula maneiras tidas como adequadas ao exercício da função de trabalhadora doméstica no que se refere ao seu modo de trabalhar, ser e agir dentro do ambiente doméstico dos empregadores. E, neste sentido, os cursos revelam uma estratégia voltada a uma perspectiva de modelagem no que concerne à trabalhadora, sobretudo enquanto pessoa, corpo e gênero, o que passa por referências de classe, de limpeza e de moralidade (Oliveira, 2007:39).

Os relatos supramencionados trazem à tona uma reflexão essencial: é possível modelar a trabalhadora, ou, se preferirmos, domesticá-la, sem humilhá-la? A resposta para esses questionamentos será dada na seção seguinte. Contudo, é possível adiantá-la em poucas palavras, já neste momento: não existe emprego doméstico sem situações de humilhação.

\section{AS HUMILHAÇÕES EM ATOS: O ALARGAMENTO DA DISTÂNCIA SOCIAL}

A contribuição fundamental deste artigo para o entendimento das dinâmicas sociais do cotidiano do emprego doméstico consiste no seguinte: propor que, quando a distância social entre patroas e empregadas domésticas é amplificada e, principalmente, quando é traduzida em atos, as situações de humilhação passam a prevalecer em tal cotidiano. Assim, em nossa argumentação, a ideia de distância social dá sentido às distintas formas de humilhação relatadas pelas trabalhadoras entrevistadas.

Já de início, cabe dizer que o emprego doméstico tem o poder de maximizar a sensação de rebaixamento, distância social extremada que ataca as domésticas ${ }^{13}$. Essa maximização extra ocorre porque muito do 
conteúdo do emprego doméstico é, por si só, composto por tarefas de natureza degradante. Por esse motivo, há, na ocupação, uma feição humilhante que lhe é intrínseca e que não precisa, necessariamente, ser fortalecida pela ação de outrem. Em outras palavras, o emprego doméstico capta mais facilmente imagens negativas construídas supraindividualmente; e estas, uma vez que fruto de processos coletivos, pesam cotidianamente sobre a imagem das domésticas, estigmatizando-as e atacando, assim, sua autoestima.

É lógico que, quanto mais ação, mais humilhação. No caso do funcionamento do emprego doméstico, as suas tarefas, sejam elas mais ou menos degradantes, serão sempre acionadas por alguém - ou seja, geralmente pelas próprias donas da casa. Se for identificada rispidez neste processo, isso levará, de um lado, ao fortalecimento da distância social entre quem ordena e quem recebe a ordem, e, de outro, ao aparecimento das situações de humilhação propriamente ditas, quase sempre envolvidas num clima de conflito. Um exemplo:

A gente é obrigada a fazer coisas que você não gostaria de fazer. Mas você tem que fazer.

[Por exemplo, Dona Rosa?]

Por exemplo, lavar banheiro dos outro. ... catar lixo dos outro, entendeu? Então tem pessoas que eles não respeitam você, doméstica. E acha que você é doméstica, vai lá, suja e deixa do jeito que tá e você tem a obrigação, entendeu? Nesse sentido é ruim. Porque às vezes muitos fazem de propósito. Vai lá, faz aquela bagunça no banheiro. Fala assim: "a empregada tá aí". Então, nesse sentido é ruim. Eu acho muito ruim (Rosa, 41 anos, 2010).

Em vista de casos como esse, faz-se necessário reafirmar que as situações de humilhação funcionam sob a premissa da intencionalidade, o que quer dizer que as pessoas tomam suas decisões com vistas a um determinado fim (sendo este fim o próprio rebaixamento de um opositor). Dito isto, podemos passar a compreender com mais segurança porque a palavra humilhação tem tanto peso e é tão recorrente na fala das trabalhadoras. Consideremos o argumento de De Decca (2005:107) a este respeito: "Ação e reação, aquele que ofende e aquele que sofre a ofensa, isto é, quem humilha e quem é humilhado devem ser percebidos socialmente, não como indivíduos possuídos por emoções incontornáveis, mas como indivíduos prontos a desempenhar papéis sociais determinados". 
Fiquemos, por ora, focados na primeira esfera dessa equação: a esfera que aqui resolvi chamar de ação-humilhação. Vale dizer que cunhar esse termo apenas se tornou possível por meio da análise de entrevistas com domésticas, das quais alguns trechos, conforme o leitor já percebeu, vêm ilustrando este artigo desde a sua primeira seção.Tendo em vista que neste momento a importância dessas entrevistas se adensa, faz-se iminente contextualizá-las.

Colhi-as em dois momentos diferentes: em 2006 e em 2010 - o que me permitiu averiguar por quais caminhos seguiram as trajetórias de vida de duas das trabalhadoras entrevistadas, desde o nosso primeiro encontro. Mais especificamente, no primeiro ano, entrevistei, ao total, seis trabalhadoras, sendo quatro delas moradoras do município de Jandira (Dona Marisa, Jacira, Rosa e Aline), uma do município de Taboão da Serra (Tamires), e outra, do Capão Redondo (Lúcia); no segundo ano, elaborei mais quatro entrevistas, sendo três delas em Jandira (novamente com Dona Marisa e Rosa, além de uma inédita, com Suzana), e uma em Taboão da Serra (com Simone). Totalizam-se, desse modo, dez entrevistas, concedidas por oito trabalhadoras.

As entrevistas ganharam forma com base em um roteiro semiaberto, tendo sido todas elas coletadas por mim. Adotei a estratégia de procurar por entrevistadas com as quais eu não havia tido qualquer contato prévio. Além disso, preferi registrar o depoimento de trabalhadoras que não estivessem ligadas, quer a alguma instituição que aborda a luta política em prol dos direitos da categoria, quer a algum(a) empregador(a) que eventualmente fizesse parte do meu ciclo de amizades. Apenas uma trabalhadora (Aline) possuía, à época das entrevistas, o ensino médio completo ${ }^{14}$.

Conduzir essas entrevistas no contexto paulistano proporciona algumas possibilidades interpretativas interessantes. O fundamental a ser ressaltado sobre isso é que o emprego doméstico na RMSP sobrevive em meio a uma face dupla. De um lado, ele é mais impessoal e menos propenso a fazer com que as domésticas se sujeitem a relações sociais que reproduzam hierarquias fixas em demasia; isso torna-se possível devido, sobretudo, à oferta de vagas a que elas podem pleitear (o que as faz mudar de local de trabalho permanentemente). Todavia, deve-se enfatizar que, ao mesmo tempo, a ocupação nunca deixou de ser consideravelmente paternalista. Vidal (2009:180), por exemplo, não vê incoerência nesses apontamentos, uma vez que 
No universo urbano em que vivem, estas mulheres [as domésticas] não são aprisionadas em laços de dependência pessoal como pode acontecer com os camponeses. O forte turn-over das trabalhadoras domésticas lembra que elas dispõem da possibilidade de trocar de empregador, contrariamente à condição de forte sujeição dos rurais à terra em que trabalham. Isto não as impede de apelar para a troca paternalista quando lhes convém.

De fato, ao longo de seu desmembramento histórico, o modus operandi paulistano, que molda o emprego doméstico em análise, não passou incólume à compatibilização de estruturas econômicas e sociais antigas e novas. A ocupação possui raízes antigas, mas, apesar de suas transformações, não desapareceu frente aos avanços tecnológicos ou à reestruturação dos padrões familiares. Talvez para o desespero de muitos(as) empregadores(as), que veem o dia a dia do emprego doméstico como um verdadeiro campo de batalhas, não há, na São Paulo de hoje, robôs protagonizando o emprego doméstico, tal como ocorre em alguns desenhos animados futuristas; há, sim, trabalhadoras estigmatizadas, desempenhando uma ocupação igualmente estigmatizada.

Ainda mais importante, o emprego doméstico paulistano não se completou enquanto profissão, seja do ponto de vista de suas interações cotidianas, regradas, em grande medida, pelas dinâmicas da intimidade, informais por si só, seja do ponto de vista de sua incorporação de direitos $^{15}$. Neste contexto já propenso a conflitos, empregadores(as) requerem bastante das domésticas em termos de excelência profissional, mas nem sempre retribuem a elas nos mesmos termos (pagando salários dignos e arcando com os seus direitos trabalhistas, por exemplo). No meio dessa fórmula, que nunca se resolve, multiplica-se o sentimento de humilhação que ataca as trabalhadoras.

Uma verdade é que, quando liguei o gravador para entrevistar as protagonistas desta pesquisa, já com todas as observações acima apontadas em mente, não verifiquei, em suas falas, adjetivos que valorizassem o emprego doméstico para o qual emprestam os seus braços; contrapunha-se a esta perspectiva, isto sim, o fato de as situações de humilhação terem sido o carro-chefe de seus depoimentos. Relatavam, desse modo, à medida que iam se sentindo mais confortáveis com as perguntas que eu fazia, aspectos centrais da ação-humilhação, mencionada anteriormente. 
Identifiquei seis tipos principais de ação-humilhação (mas, certamente, não exclusivos), sendo que todos eles alimentam situações de humilhação específicas ao emprego doméstico. Nomeando-os, temos: 1) restrições ríspidas quanto ao contato com os patrões (por exemplo, obrigatoriedade de utilizar utensílios alimentares diferentes, a exigência do uso de máscaras, a negação e/ou restrição de alimentos etc.; 2) mania de limpeza e supervisão extrema das tarefas executadas pelas trabalhadoras; 3 ) o não reconhecimento de tais tarefas; 4 ) a escassez de direitos da ocupação e o seu pouco retorno financeiro (fatores estruturais da ocupação, mas que são, recorrentemente, definidos por meio de acordos pessoais e informais); 5) descontrole emocional dos patrões (expresso na forma de gritos, por exemplo) e; 6) acusações de roubo. Cabe reconhecer que certamente existem mais pontos que poderiam preencher esse quadro; no entanto, quantos mais houver, é provável que estejam, em menor ou maior escala, ligados a situações em que a distância social entre empregadores(as) e domésticas é, por meio de atitudes, levada a níveis inaceitáveis. Dito isto, passemos a analisar as situações de humilhação em seus cenários concretos.

Um dos constrangimentos que mais ilustra o sentido de humilhação para as domésticas diz respeito ao fato de terem comida negada ou à obrigação de utilizarem itens como luvas e/ou, principalmente, máscaras, no preparo dos alimentos. Sentem-se, dessa forma, forçadas a se diferenciarem de seus(suas) contratantes, sobretudo, porque estes(as) raramente tomam os mesmos cuidados higiênicos que exigem das trabalhadoras. Isso faz com que as domésticas vejam, por meio destas exigências, o distanciamento social entre si e seus(suas) empregadores(as) ser transformado em rebaixamento e, a partir daí, já se consideram imersas em uma situação que classificam como degradante. Por esse motivo, quando se esforça para sistematizar o que seria humilhação, Dona Marisa, uma de minhas principais entrevistadas, atribui-lhe os seguintes contornos:

A humilhação é parte de patrão esconder comida, pra empregada doméstica ter que levar comida de casa, porque ela não pode comer na casa. Tudo que faz tem que ser com luva, com máscara. Porque eles acham que porque é empregada doméstica ela é contaminada. Ela vai pegar alguma doença, né? (Dona Marisa, 40 anos, 2006).

Do lado inverso do extremo distanciamento social entre empregadoras e domésticas, no cotidiano que dividem, encontra-se a proximidade espacial destas. Contudo, o fato de haver a quebra abrupta do contato so- 
cial entre empregadores(as) e trabalhadoras, com a intenção de estabelecer limites rígidos definidos entre ambos(as), abre caminho ao entendimento da ideia de "contaminação"; e esta, à medida que detectada pelas trabalhadoras, ajuda a configurar mais uma situação de humilhação característica ao emprego doméstico. É importante enfatizar que a maneira como a alimentação é distribuída nos lares das patroas é, realmente, um intenso foco incitador de tal situação: "Eu já tive patrão que eles tinham que comer primeiro, os empregados depois, come o que sobra, né? E tinha dia que levantava, nem 'oi', nem 'bom dia', nem 'boa tarde' não falava" (Suzana, 33 anos, 2010).

O poder nunca deixa de ser percebido pelas domésticas nas casas em que trabalham (afinal, uma, com maior ou menor trato, deve mandar, e a outra, com maior ou menor subserviência, deve obedecer). Começa a ser mal visto, entretanto, quando ganha dimensões extremas; ou seja, quando é transformado em abuso e passa, deste modo, a ser classificado por meio de termos correlatos à ideia de "autoritarismo". Afirmando que são as patroas (e não os patrões) as que mais exigem das trabalhadoras, e fazendo alusão a quantas histórias tristes já ouviu de suas amigas domésticas, Dona Marisa tece um comentário sobre a existência de uma atitude que, a seu ver, transborda autoritarismo:

Elas têm mais o poder. São autoritárias. Têm aquela arrogância. Vem mais das mulheres.

[E elas exigem mais?]

Bem mais. Eu tive patroa que eu ia limpando ela ia com o dedo assim, atrás de pó; vê se tinha pó, vê se tinha alguma coisa bem feita. Até os quadros tinha que tá bem no lugarzinho certinho, na posição certinha; alguma coisinha que sai do lugar elas já reclama. Então a mulher é bem mais exigente, a patroa, do que o patrão. Então cê tem que conviver. Se você pegar mais algumas pessoa, cê vai ver quantas coisas triste. (Dona Marisa, 44 anos, 2010) $)^{16}$

Não deixei de entrevistar outras trabalhadoras, conforme Dona Marisa sugeriu. Dentre outras questões, elas me indicaram que a inspeção das tarefas desempenhadas pelas domésticas é uma atitude que denota uma forma extrema de demonstração de poder por parte de algumas empregadoras - principalmente de parte daquelas que quase nunca se mostram satisfeitas com os serviços prestados por suas contratadas. É, em outras palavras, mais uma maneira de indicar e, para além disso, alargar, o sentimento de distância social nos lares. De certo modo, fazer a trabalhadora sentir-se rebaixada quando essa inspeção é praticada 
tende também a ser visto como humilhação. Tal atitude entretanto, nem sempre é aceita de forma passiva. É muitas vezes o estopim para que as domésticas saiam das casas onde trabalham, e tentem melhor sorte em outra residência. Procuram, por meio desta fuga, encontrar empregadores(as) menos exigentes, e, ao mesmo passo, abrandar as cargas de tensão que tendem a acompanhar o seu cotidiano ocupacional: "Era a mulher dele; não era ele. Era uma pessoa assim, que você limpava ela vinha passava a mão para ver se tava limpo; quer dizer que ela não achava que tava limpo do jeito dela. Um dia eu até discuti com ela, acabei deixando a vassoura na mão dela e fui embora!" (Lúcia, 35 anos, 2006).

No entanto, se inspecionar demais torna as interações cotidianas das patroas com as domésticas ríspidas, por vezes insustentáveis, as expectativas das últimas quanto às tarefas que executam também merecem atenção. Elas sentem-se frustradas, por exemplo, quando não veem o seu trabalho reconhecido, pois isto significa que o esforço que despenderam teria sido em vão. Avessa ao emprego doméstico e prestes a deixá-lo (sem a menor intenção de retomá-lo), para transformar-se em uma enfermeira, Aline enfatizou, em 2006, que a ocupação é necessariamente marcada por injustiças; a maior delas é que "ninguém reconhece; você faz, faz, e nunca tá feito. E ninguém dá valor àquilo que você faz". Quatro anos mais tarde, sua amiga atribui ainda mais peso a este ponto de vista:

[Volta e meia a senhora fala em humilhação como doméstica; o que era humilhação exatamente?]

Que nem, no meu caso, tô passando roupa, daqui a pouco, tá chovendo:

- "Ah, Rosa, vai ali na venda pra mim, vai fazer não sei o que".

Poxa vida, eu tô com o meu corpo quente, tô passando roupa, qual que é a da pessoa:

- "Ela tá passando roupa, né? Não. Não pode. Ela tá com o corpo quente:

- "Ah, pega não sei o que na geladeira pra mim".

- "Ah, Rosa, não sei o que usou o banheiro. Tá sujo."

Então, isso aí eu acho muita humilhação. Você entendeu? Eu acho assim, se você é doméstica, você foi lá, limpou, viu que tá limpinho, conservar. Não custa conservar. O ruim de ser doméstica é isso: que você faz, faz, faz, faz, mas quem tá por trás de você mandando não respeita o seu serviço. (Rosa, 41 anos, 2010). 
Como vimos, as situações de humilhação, sempre tão presentes nas vozes das trabalhadoras, são, em alguma medida, indissociáveis do cotidiano do emprego doméstico. Tornam-se acirradas pela natureza de algumas tarefas levadas a cabo pelas domésticas, muitas das quais, vale relembrar, tidas como degradantes por si só; mas são acrescidas, não obstante, pelas características estruturais da ocupação, a exemplo do seu pouco retorno financeiro e de sua fragilidade quanto à absorção de direitos. A primeira parte desta afirmação pode ser evidenciada na fala de Suzana, que abandonou o emprego doméstico justamente "porque é muita humilhação. E você trabalha, trabalha e não ganha o que é devido por eles; eles não paga o que é pra pagar. É muita humilhação. Eu não voltaria a trabalhar, não" (Suzana, 33 anos, 2010).

No que se refere à absorção de direitos, cabe enfatizar que isto ainda depende muito dos acordos informais entre empregadores(as) e domésticas, além, obviamente, do conhecimento destas últimas acerca dos benefícios legais que lhe seriam garantidos. Em outras palavras, a obtenção de direitos no emprego doméstico depende, de um lado, da vontade das empregadoras em seguir as regras oficiais, e, de outro, do conhecimento das trabalhadoras no que concerne a tais regras.

Ah, porque ali eles humilhava muito, entendeu? Eles achava que só eles tinha o direito e a gente não tinha o direito, né? A minha irmã, que trabalhava ali há mais tempo do que eu, eu trabalhava junto com ela, ela queria tirar férias. Ela queria tirar trinta dias e ela [a patroa] não queria dar trinta dias, porque a minha irmã tava muito cansada, né? E ela queria que a minha irmã tirasse menos dias, quinze dias. Daí eu falei:

- "Ah, as férias são suas. Você é que tem que tomar a decisão".

Daí ela achou desaforo de eu ter falado isso pra minha irmã. Daí a minha irmã saiu de férias, ela arrumou outra, colocou no meu lugar [...]. Depois ela me dispensou. (Jacira, 38 anos, 2006).

Considerando que o emprego doméstico é um retroalimentador de situações de humilhação, esgotá-las parece ser mesmo uma tarefa impossível. Quanto mais as procuramos, mais as encontramos. Um exemplo adicional pode ser evidenciado na propensão das domésticas em evitar o descontrole emocional de seus(suas) empregadores(as), principalmente se este for extravasado sob a forma de gestos ríspidos - acima de tudo, gritos:

Patrão não gosta de empregada mesmo. Também não sou santa. Quando não gosto de uma pessoa realmente eu não vou ser gentil com a pes- 
soa. Então, se a pessoa é gentil comigo, eu sou gentil com a pessoa. Quando a pessoa é ignorante comigo, eu sou também. Então eu tenho toda a paciência; mas tem uns patrão que é preciso ter paciência com eles, são muito ignorantes, são muito chatos. Então, uma mesmo que eu trabalhei, ah, essa última, penúltima que eu tive era insuportável. Eu já tava ficando doente com essa mulher. Eu tive que sair de lá pra ficar com essa que eu tô, porque a mulher era tão insuportável que deixava qualquer pessoa doente.

[Insuportável? O que ela fazia?]

Era uma pessoa ignorante. Ela acordava estressada. Acordava brigando com as pessoas. Nada pra ela tava certo, esse tipo de coisa assim, entendeu? Que deixa você irritado, confuso, entendeu? (Tamires, 40 anos, 2006).

Quando uma doméstica se diz humilhada, significa que se sente rebaixada a tal ponto que vê alguns de seus principais preceitos morais quase totalmente destruídos. Mas não apenas isso: sente também que sua dignidade foi reduzida bem próxima ao zero. As acusações de roubo são avassaladoras justamente por constituírem esse duplo papel. Elas revertem ao extremo o modo como a doméstica quer ser percebida: de uma trabalhadora eficiente e confiável, passa a ser classificada, nesses casos, como uma criminosa malvista e malquista.

E quem já viveu situações similares de modo gratuito, e teve que, diante disso, provar a sua inocência, só pode atribuir-lhes um rótulo: o da própria humilhação ${ }^{17}$. No caso do depoimento abaixo, a trabalhadora entrevistada afirma ter tido que enfrentar, de uma só vez, o interrogatório da patroa, e a perseguição de uma colega de trabalho:

[Me diga uma coisa: você falou sobre humilhação. Você conseguiria explicar melhor o que é humilhação?]

Tipo assim, uma vez eu trabalhei numa casa de uma pessoa e ficava eu na casa. Eu sozinha. E sumiu uma camisa da patroa. E aí tinha uma outra pessoa que trabalhava também na casa. E me acusou que eu tinha pegado a camisa. Que ela tinha me visto na condução vestindo a camisa da patroa. E sendo que eu não tinha pegado. E aí ela me mandou embora, me acusou que eu tinha pegado a camisa. Eu falando pra ela que eu não tinha pegado a camisa e ela me acusou que eu tinha pegado a camisa. Então, pra mim, isso foi uma humilhação (Suzana, 33 anos, 2010).

É importante enfatizar que todos os conflitos supramencionados são, por assim dizer, exemplos do que defini como ação-humilhação. Isto sig- 
nifica dizer que alguém, de forma mais ou menos intencional, tomou atitudes que fizeram com que se distanciasse socialmente de quem o incomoda, rebaixando esse alguém, em caso de um distanciamento que se quis extremo, e que realmente foi interpretado como tal.

\section{PAGAR COM A MESMA MOEDA}

A humilhação aquece um jogo complexo, que abarca não apenas ação, mas também reação. Esse jogo deve ser entendido em sua amplitude. Para tanto, devemos compreender, não obstante, esse seu segundo ato; de modo mais específico: quais são as reações possíveis para uma empregada doméstica que se vê diante de uma situação de humilhação em seu ambiente de trabalho?

Desde já, adiantamos que essas não podem ser quaisquer reações; para que sejam eficientes, elas precisam constituir uma resposta à altura, $\mathrm{o}$ que significa afirmar, em outros termos, que é necessário que tenham força para causar certa reciprocidade no ato de humilhar. Em linguagem popular cotidiana, todavia, nem por isso pouco elucidativa, essa máxima encontra sentido em frases como "pagar fulano com a mesma moeda". Ainda que esta vontade colida com a tradição cristã brasileira, é fortemente fomentada por quem se sente rebaixado, e se vê diante de uma situação que considera adversa, ou, ainda pior, injusta.

O que nos interessa, de modo mais concreto, é que, sem essa reciprocidade reparadora, muito provavelmente as domésticas não conseguirão reencontrar, de forma satisfatória, a dignidade que julgam ter perdido. Afinal, não se pode "pagar alguém com a mesma moeda" quando, na ocasião do reembolso, não se tem uma moeda de mesmo peso $^{18}$. É possível, entretanto, atribuir validade teórica a esta consideração que, em princípio, pode parecer excessivamente ordinária:

A situação humilhante é, por definição, racional: comporta uma agressão na qual o sujeito (individual ou coletivo) fere, ultraja uma vítima sem que seja possível uma reciprocidade. A ausência de reciprocidade é aqui essencial. Uma humilhação provisória, um comentário injurioso, uma ameaça podem ser reparados por uma resposta à altura da agressão recebida, no caso de existir uma resposta possível. Mas, a humilhação não reparada é essencialmente desigual e, com frequência, durável; o domínio é exercido em proveito do ator e em detrimento da vítima. (Ansart, 2005:15, ênfases minhas) 
É justamente essa falta de reciprocidade que faz do emprego doméstico um locus por excelência de situações de humilhação: quando estas últimas ganham força, as domésticas têm pouco poder para subvertê-las. Essa afirmação é validada pelo fato de que elaborar uma resposta à altura, em um cotidiano cujo combustível principal é a desigualdade de poder, é uma tarefa que beira à inviabilidade; como é de se imaginar, tal resposta será quase sempre deficitária.

Afirmar, porém, que as domésticas não possuem ferramentas para retribuir uma humilhação recebida em seu cotidiano de trabalho, não implica dizer que elas não consigam encontrar formas de reação, quando se sentem atacadas. Em sua pesquisa focada nos conflitos entre empregadores(as) e domésticas no Espírito Santo, Brites (2000) se deparou com algumas reações efetivas até certo ponto, uma vez que de alcance, por assim dizer, moderado. É importante antecipar que a antropóloga visualiza a contrapartida das trabalhadoras a partir de um tema bastante controverso, ainda mais quando visto sob o ângulo do emprego doméstico: o roubo.

Brites observa que o roubo, no dia a dia da ocupação, quase sempre vem à tona sob a forma de uma acusação contra a doméstica. Todavia, continua a pesquisadora, mesmo nos casos em que tal acusação tem fundamento, nem sempre culmina em um desfecho legal, o que é especialmente verdadeiro se o objeto desencadeador da contenda possui um valor banal ${ }^{19}$. De acordo com a autora, situações como essa são fruto de uma espécie de ritual performático intrínseco ao cotidiano do emprego doméstico, dado que, em muitos casos, essas situações não cindem os laços trabalhistas (e, por vezes, afetivos) estabelecidos entre contratantes e contratadas ${ }^{20}$.

Brites salienta, por fim, que, quando o roubo é realmente praticado pelas domésticas, nenhum aspecto é mais eficiente para garantir o silêncio conivente dos(as) empregadores(as) do que o fato de conhecerem em detalhes pontos por vezes embaraçosos de suas vidas (violência conjugal, casos de infidelidade etc.). Isto se mantém válido, mesmo quando os titulares das residências se sentem profundamente afrontados(as) com o desvio cometido pelas domésticas. Situações dessa ordem representariam, assim, uma moeda de troca fundamental encontrada por algumas trabalhadoras insubmissas. Na leitura de Brites (2000:128), acontecimentos como esses denotam 
a luta sobre a delimitação das fronteiras entre o "roteiro público" e "roteiro encoberto", quando os subalternos aproveitam-se das brechas de um sistema de comportamentos bem demarcados para realizar suas jogadas. Estas - com objetivos, em geral, imediatos - nunca tomam a forma do enfrentamento direto, nem da rebeldia suicida para obter algumas sobras da abundância dos ricos. Escolhem antes a falsa conformidade, a falsa deferência e, com maestria, procuram fazer os superiores morder a própria língua, comprometendo-os dentro das próprias promessas implícitas propostas em seus discursos. Aqui é necessário lembrar que neste jogo tenso entram elementos importantes como o fato das empregadas conhecerem a privacidade de seus patrões e seus eventuais desvios de conduta moral.

De fato, essas manobras pontuais podem até representar uma resposta insubmissa praticada por algumas domésticas, que decidem sentir o sabor de uma vingança momentaneamente retaliadora. Mas, sem dúvida, não tornam as interações dos(das) contratantes com as contratadas mais amenas, e não diminuem os níveis de disparidade de poder atuantes no interior do emprego doméstico, sobretudo se pautadas por atitudes socialmente condenadas, seja no nível moral, seja na esfera criminal (mesmo que, nesta última esfera, no geral, apenas formalmente) ${ }^{21}$. Tais manobras fazem com que os(as) empregadores(as) se sintam afrontados e ameaçados, mas não necessariamente humilhados, visto que a distância social entre eles(as) e suas contratadas ainda está devidamente fixada.

No mais, em vista da falta de "uma moeda com o mesmo peso", talvez seja correto pensar que uma das insubmissões mais essenciais praticadas pelas domésticas consista em fugir, na medida do possível, das situações de humilhação, as quais, em algum momento, ocorrem nas residências onde trabalham. A dificuldade que enfrentam, neste caso, é que, como vimos, essas situações são indissociáveis da natureza da ocupação que desempenham.

Em relação à fuga das domésticas, pede-se, às empregadoras leitoras de livros de etiqueta, que não nutram ressentimento contra as suas contratadas quando estas resolverem partir em busca de novas oportunidades de trabalho que lhes sejam mais interessantes; devem lutar contra toda a intimidade e sentimentalismo que recaem sobre o emprego doméstico, e jamais se esquecer de que as domésticas são, acima de tudo, "profissionais": 
Às vezes, as empregadas vão embora sem nenhum motivo aparente. Lembre-se de que ela é uma profissional como outro qualquer e obedece às leis do mercado de trabalho. É muito importante esquecer qualquer mágoa com uma saída repentina e saber separar o profissional do pessoal. Se ela foi uma boa funcionária, dê boas referências. (Matarazzo, 1995:134)

Essa partida das domésticas libera dois tipos de expectativas diferentes. Quando ela ocorre, empregadoras entram, por vezes, em desespero para encontrar outra trabalhadora que satisfaça a sua lista de prérequisitos; já grande parte das trabalhadoras espera não mais precisar satisfazer lista nenhuma; espera, simplesmente, não ter que encontrar novamente o emprego doméstico em sua vida.

Se, ainda, o momento de ruptura for marcado por tensão, o adeus das trabalhadoras assume ares para lá de dramáticos. Kofes (2001:172) imortalizou um desses momentos, ao captar o desabafo de uma doméstica que, de partida, dirige-se à sua empregadora e extravasa: "A porta da rua é a serventia da casa. A casa é da senhora, e a rua é minha".

\section{CONSIDERAÇÕES FINAIS}

Como vimos, o emprego doméstico enseja um modo de humilhação bastante específico, moderado por um jogo de proximidade e distanciamento social entre contratantes e contratadas. Em poucas palavras, prepondera, no cotidiano do emprego doméstico, a humilhação da distância social. Um grau exacerbado de distância social significa, de acordo com essa linha interpretativa, humilhação propriamente dita, sobretudo quando é expressa sob a forma de atos classificados como ríspidos, a exemplo daqueles discutidos nas seções anteriores.

O desconforto extravasado por Rosa, trabalhadora cujo depoimento embasou momentos centrais deste artigo, ilustra bem o argumento supramencionado. Em dado momento, ela elaborou uma explicação para justificar a sua recusa em sentar-se à mesa com os seus ex-patrões, mesmo mediante convite. Seu discurso saiu em voz entrecortada:

Por mais que elas tratam você bem assim, mas você sabe que você é uma doméstica, né? Entendeu? Você é doméstica. Então... é... eu acho esquisito. Eu acho estranho. Então geralmente assim, eu deixava eles almoçar primeiro, almoçava depois, ou às vezes não almoçava. Que nem eu falei, eu não tenho vergonha de comer. Só que assim, no meio de... um 
ambiente de trabalho assim, que eu sei que o meu patrão, a minha patroa, e os que estão ali. Então a gente se sente mal. A gente se sente mal. Não sei explicar pra você. Mas você não se sente bem. (Rosa, 41 anos, 2010)

Rosa nunca teve uma relação amena com o emprego doméstico. Muito a contragosto, procura-o nos períodos em que está desempregada, e afasta-se dele assim que consegue encontrar um emprego mais formal, com mais direitos trabalhistas garantidos, e, principalmente, menos aviltante aos seus olhos. Pode ser classificada como fazendo parte do exército nacional de reserva da ocupação, classificação que é fortalecida pelo fato de sempre enfatizar que nunca "foi" doméstica, mas que "teve que ser" doméstica em razão das circunstâncias adversas de sua vida (fruto da junção entre desemprego, dificuldade financeira e problemas familiares).

Entretanto, ao contrário do que gostaria, as suas idas e vindas pelo mundo do trabalho já a levaram a prestar serviços em, pelo menos, quatro casas diferentes até 2010. Neste ano, última vez em que a entrevistei, ela estava cursando o ensino médio e havia, novamente, acabado de abandonar um emprego lar adentro. Sem conter o alívio por isso, e já trabalhando como ajudante de produção em uma pequena fábrica relatava, na ocasião, que esperava não mais precisar voltar a viver do desempenho de tarefas domésticas.

Como se percebe, o cotidiano do emprego doméstico era especialmente doloroso para Rosa. Essa interpretação negativa acerca de sua experiência com a ocupação se tornava ainda mais aguda quando sentia pesar sobre si a distância social que a separava dos seus(suas) empregadores(as), mesmo quando estes(as) tentavam minimizar tal distância, convidando-a à mesa para a refeição; não precisava de muito, então, para que Rosa se sentisse humilhada.

A recusa de Rosa em dividir um momento de igualdade intrafamiliar com os seus(suas) antigos(as) empregadores(as) não é fruto de um inusitado problema de autoestima, ou de qualquer espécie de idiossincrasia que possa fazer parte da constituição psíquica de nós, seres humanos. É uma resposta consciente ao fato de que as situações de humilhação são indissociáveis do cotidiano do emprego doméstico. Rosa rejeita o convite de sentar-se à mesa com os seus(suas) contratantes porque sente que, quando presta serviço em sua residência, não pode gozar dos mesmos direitos e status a eles(as) assegurados. Dito de outro 
modo, sabe que, enquanto doméstica, o seu cotidiano é mediado por uma distância social praticamente intransponível.

Cabe reconhecer, porém, que a relação entre humilhação e emprego doméstico não é indiferente a nuanças. Decerto, o emprego doméstico é especialmente propenso a criar, disseminar e perpetuar situações de humilhação. Em adição aos ataques mais diretos, centralizados nas domésticas, tal condição intensifica-se com base na seguinte conformação social: a mesma intimidade que prepondera nos lares, aproximando, sob certas circunstâncias, os seus atores sociais, é, a partir de determinado momento, responsável por acirrar o sentimento de distância social aos olhos das trabalhadoras.

Quero dizer, com esta observação, que a distância social entre contratantes e contratadas não se configura apenas como resposta às atitudes despóticas eventualmente praticadas pelos(as) primeiros(as). Muitas vezes, conforme se depreende do desconforto de Rosa, até mesmo condutas mais igualitárias, a exemplo de convidar a doméstica a sentar-se à mesa para a refeição, não conseguem ultrapassar os alcances da humilhação; mais importante que isso, podem resultar nesse sentimento em um futuro próximo.

Ao que parece em princípio paradoxal, atitudes igualitárias guardam uma nocividade implícita, pois, ainda que sejam eventualmente estendidas às trabalhadoras, não o são sem limites muito bem estabelecidos. O problema, nesse contexto, reside justamente nos alcances desse limite, pois, mesmo que moderado, ele indica um veto e uma recusa nítidos. Em especial, quando a mencionada recusa aparece, ou seja, quando as atitudes que ganham forma no cotidiano do emprego doméstico demonstram às trabalhadoras a confirmação de desigualdades intransponíveis, principalmente depois de elas terem experienciado, ainda que tenha sido apenas em discurso, o oposto, a sensação de ser humilhada retorna fortemente ao seu universo interpretativo. Isso causa nelas decepção, angústia, frustração, raiva e sentimentos correlatos. Numa só palavra, sentem-se, desse modo, rebaixadas, para retomarmos o termo que sintetiza o fim máximo de uma humilhação acionada.

Essa configuração social de linha tênue, adicionada à estigmatização da ocupação construída por meio de força coletiva e histórica, faz com que as situações de humilhação estejam sempre à espera das domésticas, para onde quer que elas se dirijam. É por esse motivo que, no que 
tange às situações de humilhação atreladas ao emprego doméstico, mudar de ambiente de trabalho significa, para as trabalhadoras, vivê-las em maior ou menor frequência; mas jamais se livrar delas por completo.

Com vistas às suas experiências como trabalhadora na casa de terceiros, Rosa provavelmente teceu, ao seu modo, todas essas considerações, optando por abandonar o emprego doméstico sempre que vislumbrou a possibilidade. Assim também o fez Tereza de Lourdes Pires, uma ex-doméstica cujo depoimento ilustrou um dos trechos da reportagem da Veja São Paulo, revisitada na primeira seção deste artigo. Sob o sugestivo título de "Vassouras Nunca Mais", o depoimento aborda as razões das decepções de Tereza com o emprego doméstico; foram justamente essas decepções que a levaram ao rompimento com a ocupação, decisão que lhe causou profundo alívio: "Minha autoestima está bem melhor. As pessoas passaram a me olhar diferente" (Veja São Paulo, 2011:34, ênfase minha).

Curiosamente, a entrevistada se refere a uma "diferença positiva", que deriva de olhares de aprovação a ela dirigidos pelo fato de ela não ser mais doméstica; no lado oposto de seu depoimento, está implícita uma "diferença negativa", um estigma propriamente dito, que acompanha as domésticas dentro e fora das casas onde trabalham. É exatamente esta última "diferença" que persegue as domésticas. É também ela que, de modo constante, corrobora para que as trabalhadoras se vejam e sejam vistas como socialmente distantes de grande parte do mundo que as cerca, sensação que é intensificada à medida que captam sinais de reprovação social voltados contra si. Diante da força dessa realidade, difícil imaginar que elas estejam "com a bola toda".

(Recebido para publicação em setembro de 2012) (Reapresentado em setembro e novembro de 2013) (Aprovado para publicação em novembro de 2013) 


\section{NOTAS}

1. A revista São Paulo, do Grupo Folha, publicada em 05/02/2012, também abordou os atuais desentendimentos entre patroas e empregadas domésticas no contexto paulistano. Aproveitou a repercussão de Histórias Cruzadas (The Help, 2011), filme que enfoca as interações conflituosas de empregadas domésticas negras e suas famílias empregadoras, brancas, no estado sulista do Mississipi (EUA) em plena década de 1960, período em que as reivindicações por direitos civis explodiam naquele país. As fotos que ilustram a reportagem da revista São Paulo são dignas daquele contexto histórico, com patroas brancas posando com suas funcionárias uniformizadas, algumas das quais, negras. Apesar da ênfase no conflito entre patroas e domésticas, a reportagem também anuncia, a exemplo do que se verifica na matéria da revista Veja, o favorável momento em que vivem as protagonistas do emprego doméstico paulistano; estas, sabendo de sua escassez, teriam, atualmente, maior poder para fazer valer as suas reivindicações. Nas palavras da revista: "Empregadas domésticas estão em falta na cidade. Pelo menos, as boas, segundo as patroas. Elas reclamam da pouca fidelidade das trabalhadoras e da oferta cada vez menor das que aceitam dormir no emprego. Também faltam bons patrões, na visão de quem cozinha e faxina. As queixas vão da jornada de trabalho ilimitada à falta de vontade em conceder direitos trabalhistas" (Genestreti, 2012).

2. Adoto a opção analítica de substituir o termo emprego doméstico por ocupação sempre que julgar necessário. Baseei tal escolha no fato de as relações entre patroas e empregadas domésticas serem mediadas por ganho salarial, mesmo que este ganho seja, por vezes, decidido em um contexto de informalidade e de acertos pessoais. Na formulação de Johnson (1997:241), por exemplo, o termo "ocupação" difere de "trabalho" justamente por envolver transação monetária: "o trabalho é em geral considerado como ocupação apenas se resultar em ganho monetário". Por analogia, utilizo o termo trabalho doméstico para designar as tarefas do lar quando praticadas de forma não assalariada, e emprego doméstico para referir às ocasiões em que estas são repassadas para outrem, mas, neste caso, envolvendo salário. É somente neste último sentido que trato emprego doméstico e ocupação como termos equivalentes.

3. Com uma abordagem mais popular, matéria do jornal Agora, de São Paulo, publicada em 22 de abril de 2012, também enfatiza o suposto bom momento das domésticas no contexto paulistano. De acordo com a articulista do jornal, as domésticas da cidade hoje "rejeitam o rótulo de coitadinhas", sobretudo porque teriam um maior acesso a bens de consumo. Este discurso, que dá o tom de toda a matéria, foi utilizado para caracterizar a atual situação de uma doméstica entrevistada: “Com autoestima lá em cima, Patrícia chega à casa das patroas de carro, comprado no ano passado, viaja à praia 'quase todos os finais de semana' e divide com o marido o orgulho da casa própria" (Poli, 2012).

4. Os dados do Departamento Intersindical de Estatística e Estudos Socioeconômicos (Dieese) não são segmentados por categoria de serviço doméstico. Eles atestam que os salários das empregadas domésticas na RMSP, embora defasados quando comparados aos de outras ocupações, são, de uma forma geral, os mais altos do país: "O rendimento médio real por hora das empregadas domésticas, em 2009, foi bem menor nas regiões metropolitanas do Nordeste. Em Fortaleza foi de R \$1,71 por hora em média e em Recife, $R \$ 1,87$. Já em Salvador, a média recebida foi de $\mathrm{R} \$ 2,08$ por hora. Nor- 
malmente, os maiores salários médios são registrados no Distrito Federal, principalmente pela presença do Serviço Público. No caso das trabalhadoras domésticas, porém, o maior rendimento foi observado em São Paulo, capital onde o custo de vida é dos mais elevados do país, com $R$ \$3,52 por hora, seguido de Porto Alegre, $R$ \$ 3,51 por hora e pelo Distrito Federal, R \$3,08" (Dieese, 2010a:11). No entanto, em comparação às outras ocupações, os salários de empregadas domésticas são ainda os mais baixos. No caso específico da RMSP, “o montante recebido por hora pelas domésticas equivale praticamente à metade do recebido pelo total de ocupados $(R \$ 7,08)$ e a um terço do recebido por homens não-negros $(\mathrm{R} \$ 9,11)$. Restringindo-se a comparação ao contingente feminino, o rendimento médio por hora das domésticas corresponde a menos da metade do recebido nos Serviços ( $\$ 7,59)$, é bem menor do que o auferido na Indústria $(R \$ 6,19)$ e apresenta diferença menos acentuada em relação ao Comércio (R\$ 4,59)" (Dieese/PED, 2010b:9).

5. A faixa salarial das domésticas, bem como os encargos sociais previstos para a sua categoria, são duas preocupações constantes por parte de empregadores(as) que veem com reticência a implementação da chamada PEC das Domésticas, aprovada em março de 2013 no Senado Federal. Com uma interpretação conservadora, diretamente ligada à perspectiva das socialites paulistanas, Danusa Leão, colunista do jornal Fotha de S. Paulo, escreve, alarmada: "no Brasil, muitos apartamentos de quarto e sala têm quarto de empregada, e se a profissional mora no emprego, fica difícil estipular o que é hora extra, fora o 'Maria, me traz um copo de água?'. E a ideia de dar auxílio creche e educação para menores de 5 anos dos empregados, é sonho de uma noite de verão, pois se os patrões mal conseguem arcar com as despesas dos próprios filhos, imagine com os da empregada. Quem vai empregar uma jovem com dois filhos pequenos, se tiver que pagar pela creche e educação dessas crianças? É desemprego na certa" (Leão, 2013).

6. Distância social é, neste caso, definida com base "[n]o grau em que pessoas estão dispostas a aceitar e associar-se com aqueles que têm características sociais diferentes" (Johnson, 1997:74-75). O termo distância social foi inicialmente cunhado por sociólogos estadunidenses que objetivavam medir, principalmente, os níveis de segregação racial vigentes naquela sociedade; pretendiam compreender, de modo mais específico, os mecanismos e a intensidade desse tipo de segregação no âmbito das relações pessoais e cotidianas. Se procurarmos por uma formulação mais precisa, veremos que distância social é o "grau de associação limitado por convenções, preconceitos, diferenças culturais e outros fatores inerentes à própria organização social. Todas as relações subordinativas caracterizam-se por um grau variável de distância social. Quanto maior a distância que determinado indivíduo deseja guardar com relação a outro, tanto maior o grau de participação da personalidade na relação estabelecida. Entre os membros do próprio grupo, a distância é mínima; entre membros de grupos estranhos, ela é máxima" (Dicionário de Sociologia, 1974:102).

7. Dependendo do contexto em que a palavra "empregada" é utilizada (isto é, sobretudo se em um momento de confronto, em que está se construindo uma relação de poder), apenas ela é suficiente para naturalizar a imagem das trabalhadoras, colocando-as, assim, em um local social desvantajoso. Santos faz essa observação de um modo mais direto, relacionando-a às reivindicações políticas de (alguns) sindicatos representantes da ocupação: “Sabe-se que o termo 'empregada' é carregado de um sentido negativo, pejorativo, herdado das formas de execução e das relações de tra- 
balho doméstico no Brasil colonial. Esse termo tem sido utilizado, com frequência, para designar uma pessoa que possui um trabalho, que está ligada ao mercado de trabalho, ou seja, que não está desempregada. Quando assume o sentido da frase 'fulano está empregado', ou seja, fulano está trabalhando, figura com um sentido positivo. Já quando se muda a palavra 'está' para a palavra 'é', principalmente no serviço doméstico, o termo ganha uma carga depreciativa: 'fulana é empregada doméstica'. O 'é' assume um sentido naturalizante, como se a ocupação da doméstica fosse um modo de vida permanente, totalmente correspondente com a subjetividade e a posição que ela ocupa na estrutura social. Daí as representantes do Sindicato dos Trabalhadores Domésticos reivindicarem o uso do termo 'trabalhadora doméstica' ao invés de 'empregada doméstica'”' (Santos, 2010:115-116).

8. Depois que os principais problemas desta pesquisa já estavam devidamente delineados, duas empregadoras foram entrevistadas em caráter exploratório, a partir de um questionário semiestruturado. Tais empregadoras não fazem par com as trabalhadoras que protagonizam este artigo.

9. Entendo estigma em acordo com a clássica definição de Goffman (1980:7), para quem tal conceito expressa "[...] a situação do indivíduo que está inabilitado para a aceitação social plena". O estigma ganha vida incorporando marcas sociais que, em determinada situação, agem sobre a figura do indivíduo, relegando-o a um local social desprivilegiado, caso esse indivíduo possua uma marca social tida como negativa.

10. Mesmo que velada, é justamente o ato, ou, se se preferir, o comportamento, que diferencia a discriminação do preconceito. É assim que Guimarães (2004:18) a define, pensando-a no contexto das relações raciais brasileiras: "a discriminação racial consiste no tratamento diferencial de pessoas baseado na ideia de raça, podendo tal comportamento gerar segregação e desigualdades raciais. Por outro lado, o preconceito seria apenas a crença prévia (preconcebida) nas qualidades morais, intelectuais, físicas psíquicas ou estéticas de alguém, baseada na ideia de raça. Como se vê, o preconceito pode manifestar-se, seja de modo verbal, reservado ou público, seja de modo comportamental, sendo que só neste último é referido como discriminação".

11. Apesar disso, argumentei em ocasião anterior, a partir da sugestão da professora Nadya Guimarães, a quem eu agradeço, que os laços de amizade e as situações de humilhação que o emprego doméstico faz nascer não são exatamente incompatíveis em seu cotidiano: "No que diz respeito a esses laços de amizade, eles parecem, em princípio, antagônicos às situações de humilhação. Mas não o são. Ambos se constituem, no cotidiano do emprego doméstico, como fenômenos complementares. São, por assim dizer, o mesmo do outro, duas categorias de emoção muito próximas. Agem assim: os laços de amizade dialogam mais de perto com modos de interação marcados por tendências igualitárias e por pouca distância social, enquanto as situações de humilhação tendem a caminhar no sentido contrário. Contudo, no cotidiano do emprego doméstico, tanto os primeiros como as últimas fazem parte de um mesmo contínuo de interações. E, nesse contínuo, humilhação não extingue amizade, embora a primeira seja, no geral, preeminente em relação à última" (Freitas, 2010:132-133).

12. Trata-se do livro A Aventura de Ser Dona de Casa, de Tania Kaufmann, publicado originalmente em (1975) pela Editora Artenova.

13. Devemos esclarecer, em nosso vocabulário conceitual, o fato de que rebaixar é palavra-chave neste contexto, pois "a humilhação é um rebaixamento moral que afeta o 
bem-estar psicológico e físico, atinge o amor próprio e viola os princípios de respeito e de dignidade humana" (Roquette Lopreato, 2005:248, ênfases minhas).

14. Quanto ao nível de escolaridade das domésticas na RMSP, vale notar que "a maioria não chegou a concluir o ensino fundamental nos dois anos analisados $(76,7 \%$, em 2000 e 60,2\%, em 2009). Ou seja, esse tipo de ocupação, por não exigir níveis de instrução elevados, constitui uma das poucas possibilidades hoje existentes para o emprego de pessoas com baixa escolaridade, como é o caso de muitas mulheres adultas. Entretanto, nota-se que aumenta a importância da participação de trabalhadoras com ensino médio completo ou superior incompleto (de 6,7\%, em 2000 para 20,2\%, em 2009), o que expressa a melhora do nível de escolaridade da população nos anos recentes. Possivelmente isso também indica uma importante diferenciação das ocupações englobadas como serviços domésticos, tais como as de babás e acompanhantes de idosos (estas com tendência a aumentar sua presença diante do envelhecimento da população, da diminuição do tamanho das famílias e da maior inserção feminina no mercado de trabalho), além de outras relacionadas à prestação de serviços de saúde no domicílio, que requerem maior qualificação e escolaridade. Essas ocupações, no total de empregados domésticos, aumentaram de 7,9\%, no biênio 1999/2000, para 11,3\%, em 2008/2009"' (Dieese/PED, 2010b:6-7).

15. Do total de empregadas domésticas na RMSP em 2009, 69,2\% eram mensalistas; destas, apenas 36,5\% trabalhavam com registro em carteira (Dieese, 2010b:7). Com base nestes números, não há exagero em afirmar que a informalidade e a pessoalidade ainda marcam consideravelmente o cotidiano da ocupação.

16. Não restam dúvidas de que a disparidade na divisão sexual do trabalho doméstico nos lares brasileiros e a consequente absorção de maior parte deste trabalho por parte do público feminino são fatores determinantes para que os conflitos gerados pelo emprego doméstico se deem, em primeiro plano, entre patroas e empregadas domésticas. É elucidativo mencionar, a este respeito, que desde 2001 a PNAD incorporou uma questão sobre o tempo médio que homens e mulheres dedicam às tarefas domésticas. As respostas obtidas não são exatas, pois dependem da percepção dos entrevistados, os quais estimam um tempo médio que reservariam a tais tarefas: “Em 2007, enquanto as mulheres com 16 anos ou mais dedicavam, em média, 27,2 horas por semana a essas atividades, os homens responderam dedicar 10,6 horas, quase três vezes menos. Esta diferença pouco se alterou entre 2001 e 2007 - na primeira vez em que o dado foi levantado, a média de horas era de 30,9 para as mulheres e 11,2 para os homens. É relevante o fato de as mulheres declararem dedicar aos afazeres domésticos quase 4 horas a menos do que declaravam em 2001. Este fato pode ser explicado pelo aumento de sua presença no mercado de trabalho neste período ou, ainda, pela expansão do trabalho doméstico remunerado. Alternativamente, o acesso a alguns equipamentos, como máquina de lavar roupas e forno micro-ondas pode contribuir para esta redução" (Pinheiro et al., 2009:35).

17. Certa carga de suspeita sempre ronda a figura de empregadas domésticas. Por isso, a confiança é sempre tomada como um pré-requisito na hora de contratá-las. É isso o que diz Ana Lúcia, uma empregadora de 31 anos: "No meu caso, como eu trabalho o dia inteiro, e o meu marido também, a principal é a confiança; tem que gostar de cachorro, porque eu tenho cachorro, e ser maleável, que possa, sei lá, ter um gênio bom, que possa se dar com o resto da família". 
18. Não raro, a pessoa humilhada almeja retribuir a humilhação que lhe foi dirigida com "uma moeda de maior peso", para que se sinta totalmente vingada, passando, assim, de humilhada a humilhadora.

19. Brites reflete sobre as implicações geradas pelo roubo de um cacho de bananas, por exemplo.

20. Sobretudo, porque algumas empregadoras entrevistadas por Brites também se dizem culpadas: admitem "trazer", eventualmente, objetos banais de seus respectivos empregos para os seus lares.

21. Na realidade, uma reação nesses termos apenas pode ser levada a cabo por quem consegue se livrar da reprovação social voltada para quem pratica roubo, o que não se aplica a qualquer pessoa; no geral, é de se prever que a reprovação social a essa conduta fora da lei aumenta ainda mais os níveis de maculação social aplicados às domésticas. 


\section{REFERÊNCIAS BIBLIOGRÁFICAS}

ANSART, Pierre. (2005), "As Humilhações Políticas”, in I. Marson e M. Naxara (orgs.), Sobre a Humilhação. Sentimentos, Gestos, Palavras. Uberlândia, EDUFU, pp. 15-48.

BRITES, Jurema. (2000), Afeto, Desigualdade e Rebeldia: Bastidores do Serviço Doméstico. Tese de Doutorado, IFCH-UFRGS, Porto Alegre.

DE DECCA, Edgar Salvadori. (2005), "A Humilhação: Ação ou Sentimento?”, in I. Marson e M. Naxara (orgs.), Sobre a Humilhação. Sentimentos, Gestos, Palavras. Uberlândia, EDUFU, pp. 105- 117.

DICIONÁRIO DE SOCIOLOGIA. (1974). Porto Alegre, Editora Globo.

DIEESE/PED. (2010a), "As Características do Trabalho Doméstico Remunerado nos Mercados de Trabalho Metropolitanos". Disponível em <http://www.dieese.org.br/ped/metropolitana/pedãmetropolitanaMulher2010.pdf >. Acesso em março de 2010.

. (2010b), “O Emprego Doméstico no Período de 2000 a 2009”. Disponível em <http:/ / www.dieese.org.br/ped/sp/pedspMulher2010.pdf>. Acesso em março de 2010.

ELIAS, Norbert e SCOTSON, John L. (2000), Os Estabelecidos e os Outsiders: Sociologia das Relações de Poder a partir de uma Pequena Comunidade. Rio de Janeiro, Jorge Zahar Editor.

FREITAS, Jefferson Belarmino de. (2010), Desigualdades em Distâncias. Gênero, Classe, Humilhação e Raça no Cotidiano do Emprego Doméstico. Dissertação de Mestrado, FFLCH-USP, São Paulo.

GENESTRETI, Guilherme. (2012), “Histórias Cruzadas”. Revista São Paulo. Disponível em <http://www1.folha.uol.com.br/revista/saopaulo/sp0502201212.htm>. Acesso em fevereiro de 2012.

GOFFMAN, Erving. (1980), Estigma: Notas Sobre a Manipulação da Identidade Deteriorada. Rio de Janeiro, Zahar Editores.

GONÇALVES FILHO, José Moura. (2007), “Humilhação Social: Humilhação Política” , in B. de Paula Souza (org.), Orientação à Queixa Escolar. São Paulo, Casa do Psicólogo.

GUIMARÃES, Antonio Sérgio Alfredo. (2004), Preconceito e Discriminação: Queixas de Ofensas e Tratamento Desigual dos Negros no Brasil. São Paulo, Editora, 34/FUSP.

JOHNSON, Allan G. (1997), Dicionário de Sociologia. Guia Prático da Linguagem Sociológica. Rio de Janeiro, Jorge Zahar Editor.

KOFES, Suely. (2001), Mulher, Mulheres: Identidade, Diferença e Desigualdade na Relação Entre Patroas e Empregadas Domésticas. Campinas, Editora da Unicamp.

LEÃO, Danusa. (2013), “A PEC das Empregadas”. Disponível em <http://www1.folha.uol.com.br/colunas / danuzaleao/1251556-a-pec-das-empregadas.shtml>. Acesso em março de 2013.

LUKES, Steven. (1997), "Humiliation and the Politics of Identity". Social Research, vol. 64, no 1, pp. 36-51. 
MATARAZZO, Claudia. (1995), Etiqueta Sem Frescura. São Paulo, Companhia Melhoramentos.

MAUSS, Marcel. (1975), Sociologia e Antropologia. São Paulo, Ed. EPU/EDUSP.

NOGUEIRA, Manoela. (2011), “Elas Estão com a Bola Toda”. Veja São Paulo, ano 44, no 19.

OLIVEIRA, Emanuela Patrícia de. (2007), Cursos para Trabalhadoras Domésticas: Estratégias de Modelagem. Dissertação de Mestrado, IFCH-UNICAMP, Campinas, SP.

PINHEIRO, Luana et al. (2009), Retrato das Desigualdades de Gênero e Raça. Brasília, Ipea. Disponível em: www.ipea.gov.br. Acessado em julho de 2009.

POLI, Mariana. (2012), “Empregada Doméstica do Futuro Irá Cobrar por Hora”. Jornal Agora, A4, 22 de abril.

ROQUETTE LOPREATO, Christina da Silva. (2005), “O Respeito de Si Mesmo: Humilhação e Insubmissão", in I. Marson e M. Naxara (orgs.), Sobre a Humilhação. Sentimentos, Gestos, Palavras. Uberlândia, EDUFU, pp. 247-263.

SANTOS, Neville J. de Vilas Boas e. (2010), Desigualdade e Identidade no Serviço Doméstico: Intersecções entre Classe, Raça e Gênero. Dissertação de Mestrado, Faculdade de Ciências Sociais, Universidade Federal de Goiás, Goiânia.

SOLOMON, Robert C. (2000), "The Philosophy of Emotions", in M. Lewis e J. M. Haviland-Jones (orgs.), Handbook of Emotions. 2a ed. New York, Guilford Press, pp. 3-15.

VIDAL, Dominique. (2009), “A Afetividade no Emprego Doméstico. Um Debate Francês à Luz de uma Pesquisa Realizada no Brasil", in I. P. H. Georges e M. de P. Leite (orgs.), Novas Configurações do Trabalho e Economia Solidária. São Paulo, Annablume/Fapesp, pp. 173-192.

\section{ABSTRACT \\ Humiliation in the Daily Routine of Domestic Workers}

This article discusses situations of humiliation as intrinsic events in the daily routine of domestic workers in Greater Metropolitan São Paulo. It particularly focuses on the daily interactions between female employers and female domestic workers, taking place within what could be classified as domestic employment doing everything (in other words, lacking any limit to the tasks performed by female domestic workers). The author argues that situations of humiliation engendered by this occupation are primarily linked to the social distance acting on the meeting between the contractor and the contracted. In short, the preponderant daily routine of domestic work is the humiliation of social distance. The article is based primarily on ten interviews with female domestic workers living in Greater São Paulo, also analyzing newspaper articles on conflictive situations in the day-to-day context of domestic work.

Key words: domestic work; humiliation; social distance; discrimination; stigma 


\section{RÉSUMÉ}

Sur l'Humiliation au Quotidien du Travail des Employées de Maison

Dans cet article, on examine les situations d'humiliation comme des événements inhérents au quotidien du travail domestique dans la région métropolitaine de São Paulo (RMSP). On prend surtout en compte les interactions quotidiennes patronne-employée de maison, dans un cadre qu' on peut appeler travail domestique où l'on fait de tout (c'est-à-dire celui où il n'y a pas de définition des tâches à accomplir). On soutient que les situations d'humiliation engendrées par ce travail découlent surtout de l'écart social entre les parties contractantes. Bref, ce qui marque le quotidien du travail domestique c'est l'humiliation de la distance sociale. Dans cette recherche, on a mené dix entretiens avec des employées habitant la RMSP, et on a fait l'analyse de textes journalistiques concernant des situations de conflit vécues pendant leur travail.

Mots-clés: travail domestique; humiliation; écart social; discrimination; stigmata

\section{RESUMEN}

\section{Sobre la Humillación en el Cotidiano del Empleo Doméstico}

En este artículo, trato las situaciones de humillación como eventos intrínsecos al cotidiano del empleo doméstico en la Región Metropolitana de São Paulo (RMSP). Me centro, particularmente, en las interacciones cotidianas entre empleadoras y empleadas domésticas en lo que puede clasificarse como empleo doméstico en el que se hace todo (es decir, donde no se delimitan las tareas que ejecutarán las trabajadoras). Argumento que las situaciones de humillación que esta ocupación engendra están vinculadas, sobre todo, a la distancia social, que actúa sobre el encuentro entre contratantes y contratadas. En pocas palabras, prepondera, en el cotidiano del empleo doméstico, la humillación de la distancia social. Este artículo se basa, en primer lugar, en diez entrevistas realizadas con empleadas domésticas que viven en la RMSP; pero también se apoya en el análisis de textos periodísticos que tratan situaciones de conflicto vividas en el día a día de las personas que desempeñan esa ocupación.

Palabras clave: empleo doméstico; humillación; distancia social; discriminación; estigma 